\title{
FDI IN AUTOMOBILE IN INDIA: TIME TO REVIEW
}

Neha Agrawal ${ }^{1}$ and Dr. Sidharth Jain ${ }^{2}$

Abstract: FDI plays a very important role in the development of the country. The world's second most populous country could not attain the expected growth level in automobile sector. The growth of FDI gives opportunity to Indian industry for technological up gradation, gaining access to global managerial skills and practices, optimizing utilization of human and natural resources and competing internationally with higher efficiency. The paper examines the needs of FDI in automobile sector by analysing the FDI inflows from 2000 to 2016 .

\section{INTRODUCTION}

Automobile industry is the key driver of any growing economy. It plays a pivotal role in country's rapid economic and industrial development. It caters to the requirement of equipment for basic industries like steel, non-ferrous metals, refineries, petrochemicals, shipping, textiles, plastics, glass, rubber, capital equipment, logistics, paper, cement, etc.

In India, automotive industry is one of the largest industry showing impressive growth over the years and has been significantly making increasing contribution to overall industrial development of the country. Presently, India is the world's largest manufacturer of tractors, second largest manufacturer of two wheelers, and fifth largest manufacturer of commercial vehicles. It is the fourth largest passenger car market in Asia and the home to the largest motor cycle manufacturer.

The turnover of automotive industry was more than $45 \%$ of the manufacturing GDP of India during FY2014-15. The importance of this industry to the national economy can be seen by way of the size of its turnover compared to India's GDP and contribution across several other parameters which are as follows:

- Contribution of 7.1\% of India's GDP in 2014-15

- $27 \%$ of India's industrial GDP

- $4.3 \%$ of overall exports (second only to textiles \& handicrafts)

- $13 \%$ of excise revenues

- Incremental employment generation in excess of 19 million since FY06

- Total investment in excess of US\$ 35 bn of which US\$24 bn is contributed by automobile companies while US\$ 11 bn is contributed by automotive component companies

- $8 \%$ of the country's R\&D expenditure

- Improvement in fuel efficiency of passenger vehicles resulting in fuel savings of $8.6 \mathrm{bn}$

litres between FY06 and FY14

\section{Research objectives}

\footnotetext{
${ }^{1}$ Research scholar, Institute of Business Management, Mangalayatan University, Aligarh

${ }^{2}$ Associate Professor, Institute of Business Management, Mangalayatan University, Aligarh
} 
- To study the need of FDI in automobile in India

- To study the status of FDI in Automobile sector in India

\section{Hypothesis}

$\mathrm{H} 0$ : There is a need of FDI in automobile sector of India.

H0 : There is no significant difference in status of FDI and Indian investment of automobile sector in India.

\section{Research Methodology}

This study is based on secondary data and data were collected from the government reports, newspapers, journals, books and internet, etc.

\section{Limitations}

1. Research work will be based on secondary sources.

2. Research work will only focus on automobile industry.

\section{LITERATURE REVIEW}

Kerin, Roger A. \& Peterson, R.A. utter about the prospective of automobile sector of the country after entry of foreign players in this sector, "Until the mid-1990s, automobile industry in India consisted of just a handful of local companies with small capacities and obsolete technologies. Nevertheless, after the sector was thrown open to foreign direct investment in 1996, some of the global majors moved in and, by 2002, Hyundai, Honda, Toyota, General Motors, Ford and Mitsubishi set up their manufacturing bases. Over the past four to five years, the country has seen the launch of several domestic and foreign models of passenger cars, multi-utility vehicles (MUVs), commercial vehicles and twowheelers and a robust growth in the production of all kinds of vehicles. German auto-maker Volkswagen $\mathrm{AG}$, too, is looking to enter India. India is expected to be the small car hub for Japanese major Toyota. The car, a hot hatch like the Swift or Getz is likely to be exported to markets like Brazil and other Asian countries. This global car is crucial for Toyota, which is looking to improve its sales in the BRIC (Brazil, Russia, India, China) markets.

Having described the meaning of FDI, K. Rajalaksmi and T. Ramchandaran elobrate, "FDI is the process whereby residents of one country (the home country) acquire ownership of assets for the purpose of controlling the production, distribution and other activities of a firm in another country (the host country). Foreign direct investment (FDI) is a measure of foreign ownership of productive assets, such as factories, mines and land. Increasing foreign investment can be used as one measure of growing economic globalization. According to International Monetary Fund (IMF) definition, FDI has three components, viz., equity capital, reinvested earnings and other direct capital. Favourable Foreign Direct Investment (FDI) policy makes the entry of international players easy into India."

Dr. A. B. Lal, Dean, Faculty of Commerce \& Business Administration, CCS University, Meerut, explains the importance of FDI for India in present liberalized environment and also alarms about the vaporized nature of FDI in the following words, "With the liberalization of Indian economy, a large Indian market has been thrown open to foreign direct investment. FDI is seen as a means to supplement domestic investment for achieving a higher level of economic growth in development Most importantly, FDI is central for India's integration into global production chain, which involves production by multinational corporations spread 
across locations all over the world. Now, in India, it is the time for developing strategic plan for rising finance to action our priorities. FDI is key tool for it."

FDI is a part of international capital inflow for home country. K. Janardhanam, Nirmala M. \& Pratima Pandey express the importance of FDI for India in the following words, "International capital flows have significant potential benefits for economies around the world. Countries with sound macroeconomic policies and well-functioning institutions are in the best position to reap the benefits of international capital flows and minimize the risks. Much of these capital flows is due to trade in equity and debt markets. FDI refers to the foreign investments which are made on the basis of issue/transfer of equity/preference shares of Indian companies to foreign direct investors. In recent years, India has emerged as a desirable location for FDI by investors from the United States and many other countries. Its rapidly growing economy, low wages and educated work force have attracted FDI in the services and manufacturing sectors to serve both the Indian market and third country markets. Foreign investors' enthusiasm for India, however, has been tempered by widespread poverty, rigidity in the labour market, rising salaries and high employee turnover in some industries, an antiquated infrastructure, weakens in the overall educational system and excessive bureaucracy and corruption."

\section{Need of FDI in automobile sector of India}

There are so many reasons behind inviting the FDI. It plays a major role in developing countries like India. They act as a long term source of capital as well as source of advanced and developed technologies. Few listed reasons are

- Employment generation-it is a well-known fact that FDI creates new jobs opportunities. Investors sets up new units in target country so as to generate the employment for skilled and unskilled workforce.

- Technology and knowledge transfer- FDI helps in outsourcing knowledge from India especially in the information technology sector. Developing countries by inviting FDI can introduce world class technology and technical expertise. FDI helps to transfer the knowledge and technology, it includes sharing skills, manufacturing methods and even entire facilities.

- Setting up of $\mathbf{R} \& D$ centres- Since stable \& sustainable growth of any sector depends upon contribution of its research \& development cell towards the sector, hence similarly Indian automobile sector also need the same. It can be better provided by foreign investment. Further the heavy capital expenditure for innovative technology advancement in the industry could be catered by FDI.

- Helping the foreign currency reserves- Since long ago the foreign investment in any country always proves to be beneficial in empowering its foreign reserve.

- Economic development - with more jobs and higher wages, the national income normally increases. As a result economic growth is spurred. Inflow of FDI in various industrial units in India has boosted the economic life of country.

- Increased productivity- The facilities and equipment provided by foreign investors can increase a workforce's productivity.

- Income from tax- indirect taxes received from various foreign investors are also a source of income of the government.

\section{Status of FDI}

Total FDI inflows (From April, 2000 to March, 2016) 


\begin{tabular}{|l|l|l|l|}
\hline & $\begin{array}{l}\text { CUMULATIVE AMOUNT OF FDI } \\
\text { INFLOWS } \\
\text { (Equity inflows + 'Reinvested earnings'+ } \\
\text { 'other capital') }\end{array}$ & $\begin{array}{l}\text { US\$ 424,167 } \\
\text { Million }\end{array}$ \\
\hline $\begin{array}{l}\text { CUMULATIVE AMOUNT OF FDI } \\
\text { EQUITY INFLOWS } \\
\text { (excluding amount remitted through RBI's + } \\
\text { NRI Schemes) }\end{array}$ & $\begin{array}{l}\text { Rs. 1,495,326 } \\
\text { Crore }\end{array}$ & $\begin{array}{l}\text { US\$ 288,513 } \\
\text { Million }\end{array}$ \\
\hline
\end{tabular}

Source: DIPP,2016

Status of FDI in automobile sector:

FDI equity inflows in automobile sector From April, 2000 to March, 2016:

\begin{tabular}{|l|l|l|l|}
\hline \multicolumn{1}{|c|}{ Sector } & \multicolumn{3}{c|}{ Amount } \\
\hline & (In Rs crore) & (In US\$ million) & $\begin{array}{l}\text { \%age of total } \\
\text { inflows }\end{array}$ \\
\hline Automobile Industry & $81,394.21$ & $15,064.95$ & 5.22 \\
\hline Sub-Total & $1,495,326.10$ & $288,512.78$ & \\
\hline $\begin{array}{l}\text { RBI's- NRI SCHEMES } \\
(2000-2002)\end{array}$ & 533.06 & 121.33 & \\
\hline Grand Total & $1,495,859.16$ & $288,634.11$ & \\
\hline
\end{tabular}

Source: DIPP

Explanation: Table shows the total of FDI inflows in automobile sector in India during the last 16 years i.e. from 2000 to 2016. Upon review of the above figures it is clearly visible that the FDI in automobile sector is just $5.22 \%$ of the total inflows. Although it is of considerable nature but at the same time there is a lot of scope of improvement in the same. Over the previous years automobile giants like Honda, Hyundai, Renault, Benz etc., have entered in Indian market so it is clearly desirable to increase the share of FDI inflows proportionally.

Also if it is compared to the GDP of India which is almost \$ 2290 billion in 2016 it is amounting to only $0.66 \%$.

Further although Government of India have given a lot of substantial efforts till now , but as of now the industry is only the fifth one in terms of sectors attracting highest FDI equity inflows following service sector, telecommunication sector etc.

Hence GOI has to take measures for growth of foreign investment.

\section{SECTORS ATTRACTING HIGHEST FDI EQUITY INFLOWS:}

Amount in Rs. crores (US\$ in million)

\begin{tabular}{|l|l|l|l|l|l|l|}
\hline Ranks & Sector & $\begin{array}{l}2013-14 \\
\text { (April }- \\
\text { March) }\end{array}$ & $\begin{array}{l}\text { 2014-15 } \\
\text { (April-March) }\end{array}$ & $\begin{array}{l}\text { 2015-16 } \\
\text { (April,15- } \\
\text { March, 16) })\end{array}$ & $\begin{array}{l}\text { Cumulative } \\
\text { Inflows } \\
\text { (April '00 - } \\
\text { March '16) }\end{array}$ & $\begin{array}{l}\text { \% age to } \\
\text { total } \\
\text { Inflows } \\
\text { (In terms } \\
\text { of US\$) }\end{array}$ \\
\hline 1. & $\begin{array}{l}\text { SERVICES SECTOR } \\
* *\end{array}$ & $\begin{array}{l}13,294 \\
(2,225)\end{array}$ & $\begin{array}{l}27,369 \\
(4,443)\end{array}$ & $\begin{array}{l}45,415 \\
(6,889)\end{array}$ & $\begin{array}{l}258,354 \\
(50,792)\end{array}$ & $18 \%$ \\
\hline
\end{tabular}




\begin{tabular}{|c|c|c|c|c|c|c|}
\hline 2. & $\begin{array}{l}\text { CONSTRUCTION } \\
\text { DEVELOPMENT: } \\
\text { TOWNSHIPS, } \\
\text { HOUSING, BUILT- } \\
\text { UP } \\
\text { INFRASTRUCTURE }\end{array}$ & $\begin{array}{l}7,508 \\
(1,226)\end{array}$ & $\begin{array}{l}4,652 \\
(769)\end{array}$ & $\begin{array}{l}727 \\
(113)\end{array}$ & $\begin{array}{l}113,936 \\
(24,188)\end{array}$ & $8 \%$ \\
\hline 3. & $\begin{array}{l}\text { COMPUTER } \\
\text { SOFTWARE \& } \\
\text { HARDWARE }\end{array}$ & $\begin{array}{l}6,896 \\
(1,126)\end{array}$ & $\begin{array}{l}14,162 \\
(2,296)\end{array}$ & $\begin{array}{l}38,351 \\
(5,904)\end{array}$ & $\begin{array}{l}112,184 \\
(21,018)\end{array}$ & $7 \%$ \\
\hline 4. & $\begin{array}{l}\text { TELECOMMUNICA } \\
\text { TIONS } \\
\text { (radio paging, cellular } \\
\text { mobile, basic } \\
\text { telephone services) }\end{array}$ & $\begin{array}{l}7,987 \\
(1,307)\end{array}$ & $\begin{array}{l}17,372 \\
(2,895)\end{array}$ & $\begin{array}{l}8,637 \\
(1,324)\end{array}$ & $\begin{array}{l}92,729 \\
(18,382)\end{array}$ & $6 \%$ \\
\hline 5. & $\begin{array}{l}\text { AUTOMOBILE } \\
\text { INDUSTRY }\end{array}$ & $\begin{array}{l}9,027 \\
(1,517)\end{array}$ & $\begin{array}{l}16,760 \\
(2,726)\end{array}$ & $\begin{array}{l}16,437 \\
(2,527)\end{array}$ & $\begin{array}{l}81,394 \\
(15,065)\end{array}$ & $5 \%$ \\
\hline
\end{tabular}

Note: (i)** Services sector includes Financial, Banking, Insurance, Non-Financial / Business, Outsourcing, R\&D, Courier, Tech. Testing and Analysis

(ii) Cumulative Sector- wise FDI equity inflows (from April, 2000 to March, 2016) are at Annex-'B'.

(iii) FDI Sectoral data has been revalidated / reconciled in line with the RBI, which reflects minor changes in the FDI figures (increase/decrease) as compared to the earlier published sectoral data.

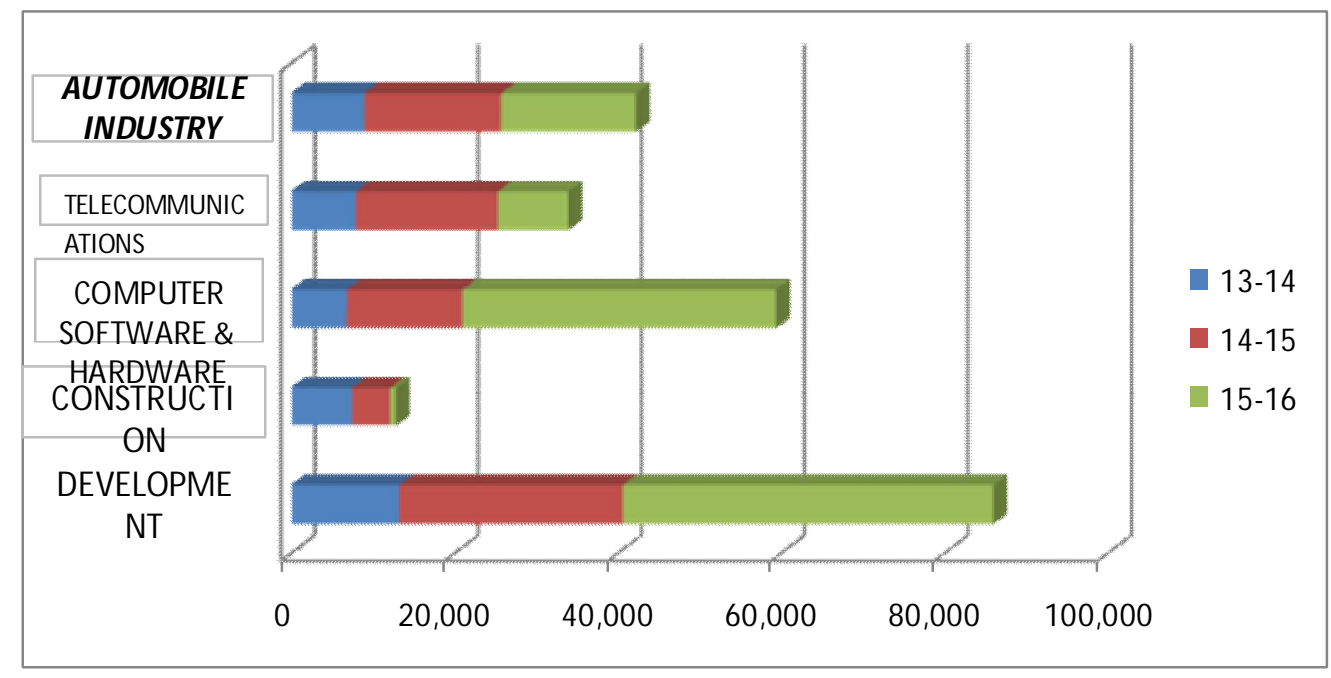

Fig 1. FDI equity inflows (amount in Rs.) 


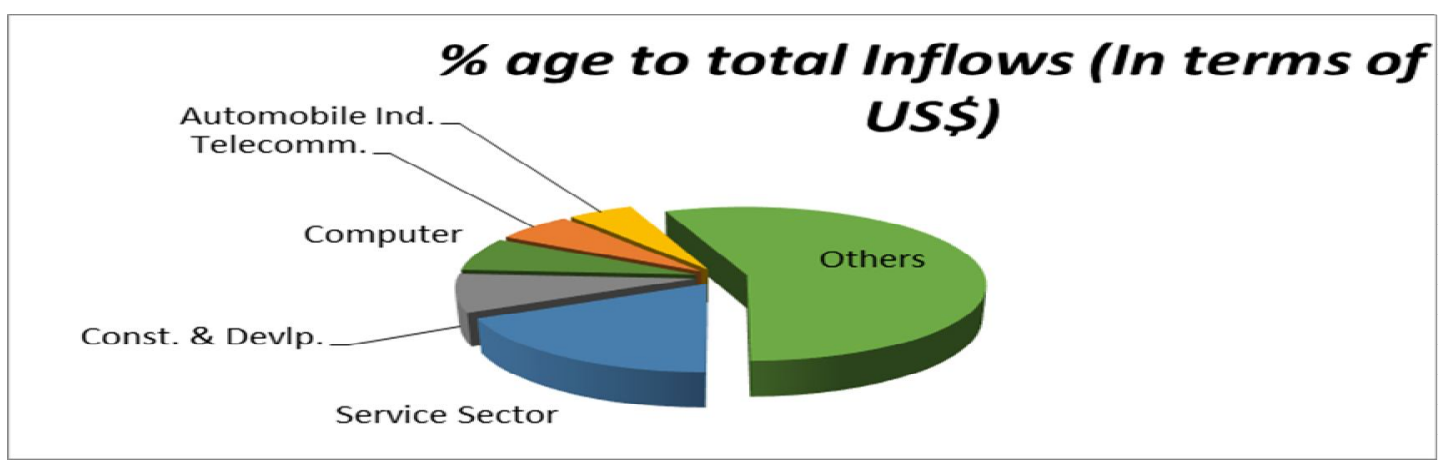

Fig. 2 percentage to total inflow of FDI in different sectors.

\section{CONCLUSION}

This study concluded that status of FDI in automobile sector is in increasing order but comparatively to other sectors is not sufficient. It needs more options for growth. Employment opportunities, economic development, productivity, technology and many other reasons evidences the need of rise in fdi in Indian automobile sector. FDI brings better technology and management, access to marketing networks and offers competition, the latter helping Indian companies improve, quite apart from being good for consumers. Foreign Direct Investment as a strategic component of investment is needed by India for its sustained economic growth and development through creation of jobs, expansion of existing manufacturing industries, short and long term project in fields like healthcare, education, research and development $(\mathrm{R} \& \mathrm{D})$ etc.

\section{REFERENCES}

[1]. Kerin, Roger A. \& Peterson, R.A.; Future of Automobile Sector in India; Allyn \& Bacon, Inc, Boston 2005, P.86.

[2]. Dr. A. B. Lal; Impact of FDI on Automobile Sector of India; An article published in the souvenir of National Seminar held on S D College, Muzaffanagar, 26-27 Nov., 2005, p.p. 17-19.

[3]. Kerin, Roger A. \& Peterson, R.A.; Future of Automobile Sector in India; Allyn \& Bacon, Inc, Boston 2005, P.86.

[4]. K. Janardhanam, Nirmala M. \& Pratima Pandey; FDI Practices in Automobile Sector; International Journal of Marketing and Technology, USA; Volume 1, Issue 1, July, 2011, p. 32.

[5]. Bajpai N., Sachs J.D. (2000), "Foreign direct investment in India: Issues and problems", HIID Development Discussion papers No.759.

[6]. Narayana B., Vashisht P.,(2008), "Determinants of Competitiveness of the Indian Auto Industry", ICRIER, working paper No. 201.

[7]. Sharma N. (2011) "Financial analysis of Indian automobile industry", Ijrcm, Vol. 1, Issue 9.

[8]. Singh A., Gupta Dr. V. (2012), "Indian Automobile Industry: A Review", IJRMET, Vol. 2, Issue 2.

[9]. Pandya H., Pandya H. (2013) "FUNDAMENTAL ANALYSIS OF INDIAN AUTOMOBILE INDUSTRY”, International journal of current research ,Vol 5,Issue 5,PP 1273-1286

[10]. Dharmraj A., Kathirvel Dr. N.(2013), "Financial Performance of Indian Automobile Industry - A Comparative Study During Pre and Post Foreign Direct Investment", International journal of scientific research, Vol. 2, Issue 9.

[11]. Gaddman J.C. (2013) "Production and sales trend of automobile industry in India" , G.J.C.M.P., Vol. 2(4),P No. 24-33.

[12]. Krishnaveni M., Vidya R. (2015) “Growth of Indian Automobile Industry”,ijcrar,Vol 3,Issue 2, PP 110118.

[13]. www.dipp.nic..in $>$ English $>$ Publications $>$ FDI_Statistics/FDI_Statistics.aspx

[14]. www.saim.com

[15]. www.makeinindia.com 